\title{
Library Literature in Mainland China: A Content Analysis Douglas W. Cooper
}

Library science in mainland China has seen substantial development since 1979. Library education and professional activities, organizations, and communications have been spurred by the establishment of the China Society of Library Science, a number of library science journals, and international exchanges. This study analyzes the library literature published in three of the mainland's journals for a recent volume year (1985) and characterizes the profession and its scholarly communication. It also compares these writings with reports about the current library scene in China published in the West and concludes that library science in the P.R.C. has yet to be adequately developed.

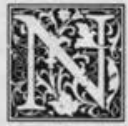

umerous recent reports in the literature suggest that the library world in mainland China is recouping the losses it suffered during the Cultural Revolution and is making great strides toward catching up with library science in the West. During this period of increased East-West contacts and exchanges, the mainland is playing host to many Western librarians who are visiting libraries and librarians to see and hear firsthand how the profession is doing. ${ }^{1}$ Several mainland librarians have published reports in Western journals on the professional scene in China. ${ }^{2}$ Overseas Chinese are also taking a closer look at the mainland's libraries ${ }^{3}$ and their role in international library cooperation. ${ }^{4}$ Two such writers recently have shed light on aspects of librarianship on the mainland, surveying library education and the profession's scholarly production in library science journals.

In order to arrive at a better understanding of librarianship as it is practiced in
China today, the authors thought it useful to compare reports published in the West with writings from the mainland library science journal literature. In order to do this, several journals recently published in mainland China were chosen for analysis. First, however, a brief sketch of the profession's governance may help to put the following discussion into perspective.

Mainland China's State Council governs all libraries through the Ministry of Culture's Administrative Bureau of Library Service. Coordination of the various types of libraries on the mainland is currently accomplished through individual library centers, such as Beijing National Library, which is responsible for all public libraries, and the China Academy of Sciences, which is responsible for all science libraries that are not a part of the Institute of Science and Technology Information Center (ISTIC). Prior to 1985, coordination was accomplished through the Ministry of Education, which is responsible for educational institutions at all levels. ${ }^{6}$ (Through

Douglas W. Cooper is Reference Librarian at the Chinese University of Hong Kong, Shatin, N.T., Hong Kong.

This paper was presented in a somewhat different form at the 1986 Library Cooperation and Development Seminar in Taiwan, August 17-18, 1986. Thanks are due to T. H. Chow, librarian of New Asia College, Chinese University of Hong Kong, for his indispensable help in coding items in the journals analyzed and to C. F. Lee, sublibrarian at the University Library, Chinese University, for his suggestions about journals to consider. 
action taken at the sixth National People's Congress, the Ministry of Education became part of the Education, Science, Culture, and Public Health Committee. ') The State Council also governs the State Commission of Science and Technology and, through it, the activities of ISTIC, a national information center with a staff of more than twelve hundred.'

\section{RECENT DEVELOPMENTS}

Since 1979 , the impetus for library development in mainland China appears to have come from a combination of indigenous efforts and foreign professional influence. One of the first exchanges of professional know-how occurred in September 1973 directly on the heels of the Shanghai Communique of 1972, when a ten-member Chinese library delegation toured libraries in the United States. This visit was followed by a stream of American librarians to the mainland. ${ }^{10}$ During the next decade, mainland library groups hosted delegations from the United States, Australia, the Philippines, Thailand, and elsewhere, while simultaneously sending delegations to the United States, New Zealand, the Federal Republic of Germany, Norway, Sweden, Denmark, and North Korea. ${ }^{\text {" China reclaimed }}$ its seat in IFLA in $1980 .{ }^{12}$ Since then, this exchange of professionals and expertise has continued through numerous workshops, cooperative ventures, visits, and exchanges, within mainland China and in several host countries. ${ }^{13}$

Hong Kong's university and polytechnic libraries and librarians have played a major role in recent developments in library science on the mainland. Hong Kong presents the prospect of a developed country with an advanced library technology, a self-assured body of professionals, and well-developed ties with the West. Since the beginning of the 1980s, China has sent a steady stream of delegations to visit the libraries of Hong Kong. In September 1982 a number of mainland librarians read papers and attended meetings at the International Federation of Documentation (FID). In December 1985 another group attended a conference at the Chinese University of Hong Kong.
Since 1981, some twenty-four groups have toured the Chinese University library, and many have also stopped at the University of Hong Kong.

During this period, mainland China has developed its program of library education and its professional activities, organizations, and communications. A number of important national conferences have been conducted-for example, those held at the Chinese Academy of Sciences (CAS) in November $1978^{14}$ and at the Ministry of Education in December of the same year, ${ }^{15}$ and two offered in $1979^{16}$ and 1980 by the newly formed China Society of Library Science, in conjunction with the United States Information Agency. ${ }^{17}$ The Ministry of Education and the Ministry of Culture each called national meetings in September and November $1981,{ }^{18}$ and the National Standards Bureau met during the same period. ${ }^{19}$

It was during this period of intense activity that the China Society of Library Science (CSLS) was created. The idea for the society developed at a meeting held in November $1978^{20}$ and the organization was established officially in July $1979 .{ }^{21}$ The antecedents of the society date back to 1925 when the Library Association of China was founded in Beijing. Although membership in the earlier group was never as large as that of CSLS today-in 1935, at its largest, there were 562 individual and 288 institutional members-it was active nationally and internationally until $1949 .{ }^{2}$ Today, the CSLS has some twenty-eight branch societies in the various provinces, autonomous regions, and direct municipalities, and a 1986 membership of 5,000 individual and 35 institutional members. ${ }^{23}$

A need for improved communication within the profession grew out of this national reorganization of librarians. The CSLS initiated its official publication, the Tushuguanxue Tongxun (Bulletin of the China Society of Library Science), with the June 1979 issue. During this same period, a number of other professional journals began publishing. The National Library of China (formerly Peiking National Library) began issuing the influential Beitu Tongxun (Peiking Library Newsletter) in 1979. The CAS started Tushu Qingbao 
Gongzuo (Library and Information Services) in 1980. The Shanghai Municipal (Public) Library began its nationally read Tushguan Zazhi (Library Journal) in 1982. In addition, many regional and provincial library societies began issuing their own journals. By 1981 , there were an estimated fifty library science journal publishing, ${ }^{24}$ a figure that has remained more or less constant since. $^{25}$

\section{METHODOLOGY}

This study attempts to determine some of the topics of concern to members of the profession in mainland China and characterizes the nature of professional writing appearing in several mainland journals. Some characteristics of the library profession itself are inferred from these concerns and writings. The types of items appearing in the issues of three leading journals published in the most recent volume year available (1985) were coded and tabulated in order to gain a clearer impression of what library science is like in mainland China today. To complete the picture, this study refers occasionally to reports published elsewhere that give differing impressions.

Several criteria were used for choosing the three journals for analysis: (1) national reputation; (2) status of the issuing body or agency; (3) appeal to a national (and, for two of the three, an international) audience; and (4) availability and influence. Although circulation figures for the three journals chosen were not readily available, comments in several recent articles support their choice. ${ }^{26}$

All three journals chosen have relatively long publication histories compared with other mainland Chinese library science journals. Further, all three emanate from large and well-established corporate organizations with national support, thus assuring at least quasi-official sanction.

The first journal chosen, the Bulletin of the China Society of Library Science (1979- , quarterly), has been referred to as "the most important library journal in China' ${ }^{\prime 28}$ and is the national organ of the society. Long, serious, and often official articles appear in its pages.

The second, Library and Information Ser- vices (1980- , bimonthly), has been called "one of the most important journals in the field. ${ }^{\prime 29}$ It is issued by the library of the prestigious Academia Sinica in Beijing (also known as the China Academy of Sciences). Appropriately, it publishes more articles concerned with science and technology than do the other two journals selected.

The third, Library Journal (1982quarterly), ranks just behind the others ${ }^{30}$ in national importance and coverage of a broad range of topics. It is issued by the Shanghai Municipal Library, one of the largest public libraries in mainland China and long one of its most important and influential cultural, publishing, and library centers. ${ }^{31}$ Library Journal publishes a large number of very short articles, including many bibliographical studies of classical Chinese works.

Since their inception, both the Bulletin and Library and Information Services have provided contents pages in English as well as in Chinese. (In 1985, the Bulletin began publishing English-language summaries of its articles.) Presumably this is done to facilitate inclusion in international indexing and abstracting services.

This study codes each item in each issue for the volume year of all three journals using two categories. These categories were devised in order to determine both subject matter and what might be called rhetorical modes or journal categories. While the categories used for this analysis may not be entirely adequate to characterize fully the items reviewed, they do serve to indicate a number of noteworthy features, both in form and content.

\section{DISCUSSION}

One early authority on content analysis discussed several uses of the method that seem particularly suited to this study. $\mathrm{He}$ suggested that it could be used to look at such aspects as focus of attention, the stage of development of scholarship, stylistic features, and comparisons of communication content with statements of professional objectives. ${ }^{32}$ The following discussion will focus on each of these aspects, summarize findings of the analysis, and, whenever possible, cite relevant ob- 
servations published in the West.

\section{Focus of Attention}

Perhaps the most revealing use of the content analysis method is what it tells us about the focus of attention of the journals we chose for our study. Heavy, moderate, and slight attention paid to certain broad topics were revealed that permit comparisons to be made with reports published elsewhere about the professional concerns of mainland China's librarians. The most heavily discussed topics were libraries and society, the library profession, technical services, and library resources (see table 1).

All three journals place great emphasis on the official role of libraries in society. Articles such as "Problems of the Library's Social Status" (Library Journal, no.4:3-7 [1985]) occur often, as do items concerned with the role of libraries in fostering proper ideological perspective among the nation's population. Many authors view the ultimate function of libraries as empirical: Will they help with the "four modernizations"? Will they help the nation catch up with other developing nations? For example, a series of articles appeared in the Bulletin in 1983 and 1984 that dealt with the dissemination of Marxism in mainland China and the role libraries play in it. A recent article in that journal dealt with, as the title indicates, how "Teaching and Publicizing Patriotism and Scientific Communism Constitute an Important Task for University and College Libraries" (no.3:36 [1985]). However, the shift in emphasis in government policy from ideology to modernization since the end of the Cultural Revolution ${ }^{33}$ is not yet fully reflected in journal content.

The library profession itself also comes in for extensive discussion in these journals as well as in the Western library press. A new generation of librarians produced since the Cultural Revolution is be-

TABLE 1

SUBJECTS

\begin{tabular}{|c|c|c|c|c|}
\hline & $\begin{array}{l}\text { Bulletin } \\
\text { of CSLS }\end{array}$ & $\begin{array}{c}\text { Library \& } \\
\text { Info. Service }\end{array}$ & $\begin{array}{l}\text { Library } \\
\text { Journal }\end{array}$ & Total \\
\hline Libraries and Society & 15 & 10 & 18 & 43 \\
\hline Lib. Profession & 13 & 8 & 26 & 47 \\
\hline Mgmt./Admin. & 6 & 13 & 11 & 30 \\
\hline Technical Services & 6 & 20 & 19 & 45 \\
\hline acquisitions & - & - & - & - \\
\hline processing & - & $\overline{-}$ & 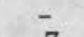 & - \\
\hline cataloging & - & 11 & 7 & 18 \\
\hline classification & 4 & 6 & 10 & 20 \\
\hline computer use & 1 & 1 & 2 & 4 \\
\hline microfilming, printing, etc. & 1 & 1 & - & 2 \\
\hline other: (binding) & - & 1 & $=$ & 1 \\
\hline Public Services & 12 & 12 & 17 & 41 \\
\hline circulation & - & - & 4 & 4 \\
\hline reference (general) & 5 & - & 9 & 14 \\
\hline personal help & 2 & - & - & 2 \\
\hline telephone & - & - & - & - \\
\hline user education & 1 & - & - & 1 \\
\hline lit. searches & 2 & 6 & 2 & 10 \\
\hline documentation & $\overline{1}$ & 4 & 1 & 6 \\
\hline indexing, trans. & - & 1 & - & 1 \\
\hline creating aids & 1 & 1 & 1 & 3 \\
\hline current awareness & - & - & - & - \\
\hline faculty liaison & - & - & $\overline{0}$ & $\overline{-}$ \\
\hline Resources & 7 & 8 & 28 & 43 \\
\hline reference materials & 4 & 5 & 16 & 25 \\
\hline collections & 1 & 1 & 4 & 6 \\
\hline preservation & 2 & 2 & 3 & 7 \\
\hline security & $\overline{-}$ & - & $\overline{2}$ & $\overline{2}$ \\
\hline $\begin{array}{l}\text { buildings } \\
\text { other (misc.) }\end{array}$ & $\overline{-}$ & $\overline{-}$ & 3 & 3 \\
\hline
\end{tabular}


ginning to take its place in a profession characterized by one overseas Chinese writer as "severely disturbed-whenyoung. ${ }^{\prime \prime 4}$ Yet only a few of China's large number of library staff members have had formal training in library science. According to another overseas Chinese, in 1981, among more than 1,000 directors and deputy directors in academic libraries, only 8 percent had any library science training. ${ }^{35}$ The majority of library workers are relatively inexperienced, having begun their work in libraries after the Cultural Revolution. This means, according to the same writer, that the profession consists largely of the old and the young, with few in between. ${ }^{36}$

This age dichotomy has resulted in the need to implement a program of education for librarianship for an entirely new generation. For this reason, the pages of these journals carry frequent reports of overseas library training programs and practice, along with profiles of outstanding figures in the history of Chinese librarianship, and publications translated and reprinted from Western library science journals-all serving to keep readers aware of professional goals and international standards.

Much discussion also centers on how improved administration and personnel management can help to foster library reform. Reflecting concern for the library profession, many writers feel that staff should be selected and promoted on the basis of merit and training. This contradicts the older practice of a life assignment made by a central or a provincial government that, in the past, often used libraries as a dumping ground for those unable to find or hold other positions due to old age, poor health, or an inability to do the work. ${ }^{37}$ One foreign observer says that there is "no established, systematic, annual evaluation of performance" nor any merit pay or other incentive system. ${ }^{38}$ Another observer has summed up the present situation thusly:

Most library staff are relegated from other departments or institutions. The library has no power to select its own staff, or to reject anyone assigned to it. Consequently, lack of selfrespect and a sense of professionalism among staff members is a common problem. ${ }^{39}$
Among topics dealing with technical services, cataloging and classification proved very popular. Until about 1980 , three classification systems coexisted in mainland China: one at the People's University in Beijing, the CAS' own system, and the less widely used one at Wuhan University. In March 1981, the Bulletin reported a national conference held in Nanning where a standardized system, the Chinese Library Classification Rules for Books (CLCRB), was agreed upon. According to a 1985 article in the Bulletin (no.1:51-5,76) a nationwide survey showed that 90 percent of all libraries now use this standard classification system.

Articles appearing mostly in Library and Information Services and Library Journal endorse the new standards while examining various problems encountered when applying them to particular subject categories. A Chinese MARC system still awaits computer software for full implementation of the CLCRB, so that there are few items here dealing with computers in any but quite general ways.

Historical studies also appear frequently in the pages of these journals. Many such studies trace the development of an especially significant collection or an unusual or outstanding library. Bibliographic studies examine the history and role of various reference sources including many classics.

Thirty-seven significant occurrences of the topic of public services were documented. Of these, most are concerned with literature searches. As reported by a mainland librarian writing in a Western journal, library staff at Tianjin University respond to requests of teaching staff by providing manual literature searches largely in scientific and technical sources. This saves faculty the time and trouble of traveling to Beijing, ${ }^{40}$ although it is possible to mail requests for computer literature searches directly to the Beijing National Library. ${ }^{41}$

A growing concern for readers' services has emerged in the last couple of years, endorsed by the popular slogan "Readers First, Service First." Library Journal, organ of the public Shanghai Municipal Library, published numerous, if brief, articles in the survey year issues, such as "The Quantity and Quality of Reader Services 
(no.4:12-13 [1985]). Library and Information Services has also carried some discussion of "remunerative information service," referring to the fee-or-free controversy in Western library circles.

Reference services and bibliographic instruction receive little attention in mainland China despite their popularity in the West. Few items deal with assistance, whether rendered through personal contact or indirectly through user education or faculty liaison. While there is some awareness of bibliographic instruction issues among library science students, there was none in evidence for several observ$\mathrm{ers}^{42}$ and only one item dealt with instruction in all fourteen journal issues examined. In contrast, the topics of resources and collections hold a continuing interest for writers, with numerous bibliographic studies of reference sources and the classics.

This concentration on sources, classics, and collections suggests that in a dichotomy between access and archives, ${ }^{43}$ the greater weight in these journals rests with archives. This is the notion that resources, properly preserved, cataloged, housed, and protected, take precedence over access, whether this access means easy availability through open shelving, interlibrary loans, or, more importantly, personal assistance from librarians who are able and interested in helping the patron locate and use them.

Perhaps this emphasis on resources is to be expected on the mainland, with its rich cultural heritage, political system, and population crunch. Further, there is less emphasis on individual achievement and self-discovery in mainland China than in the West. It also has less need for a wellinformed electorate than Western democracies. And because libraries in Communist countries are more concerned with serving the economic advancement of the nation, perhaps little need is felt to teach the average person how to use libraries as places to find information for personal development.

The emphasis on the archival function of libraries there tends to be confirmed by the reports of a number of Western librarian observers. During the latest of several consultative tours of some eight univer- sity libraries and the ISTIC, one of these librarians found a "closed-access approach and almost complete lack of reader services as we know them today." ${ }^{\prime 4}$ This same writer found that

There were no signs anywhere of what we would think of as an enquiry desk. ... What is perhaps even more indicative of the very limited activity in reader services was that we did not meet any members of staff, apart from at Huazhong, who were engaged in such reader services activities, nor indeed was there any mention of them in the syllabuses of the various Library Schools. ${ }^{45}$

Generally, other Western scholars and librarians concur in the impression of little or no reference service, ${ }^{46}$ bureaucratic inconveniences, ${ }^{47}$ only minimal concern for facilitating research, ${ }^{48}$ and "more concern with collections than services." ${ }^{\prime 49}$

However, a number of articles on public services seen in this study show some concern for adjusting the balance between the two poles of the resources-access dichotomy. Perhaps a part of this impulse toward balance comes from the fairly recent influence of Western library practice. This influence takes the form of translated reprints, abstracts, summaries, and digests of foreign library publications that appear frequently in these journals. The same influence may also come from accounts by members of Chinese library delegations who have visited the West or by students returned to mainland China.

\section{The State of Development of Scholarship}

A few of the students returning from the West and others concerned with library and social science literature in the West have been exposed to other forms of scholarly writing in library science. But, except for the work of a few, the stage of development of scholarship in mainland China seen in the three journals surveyed appears to be less sophisticated than that in the West. The relative absence of volume numbering, article abstracts, notes on author affiliation, and citations to other published literature have all been noted in previous studies. ${ }^{50}$

The exhortation in 1982 of two writers in the Bulletin to spend less time on studies of the classics and more on substantive library science research ${ }^{51}$ seems to have 
gone largely unheeded. Only eight research articles turned up in this content analysis. The analysis further revealed that of the total number of articles (233, including 16 bibliographic essays) only 15 percent had a bibliography appended and a mere 6 percent provided citations in footnotes.

While editorial policy can influence article format, nonetheless the results of the analysis imply little concern with contributing to a cumulative body of scholarship. Another possible explanation is that librarians in mainland China have a view of library science quite different from that of their counterparts in the West and do not see the discipline as one of the social sciences with an established and growing body of knowledge. Nowhere in any of the three journals surveyed was there evidence of-or reference to-any essay resembling an annual review of scholarship (see table 2).

\section{Stylistic Features}

Stylistic features in the journal issues examined also reflect less-developed scholarship. Some of the effects of a SocialistCommunist political system turn up in the numerous items of exhortation and commendation. Sloganizing appears in the writing of all three journals and perhaps is heaviest in the official Bulletin, which emphasizes the social importance of propaganda. Exhortation to work, improve, and reform recur constantly. While research reports are very few, all three journals tend to have a large number of work experience accounts. An even greater number of speculative essays and opinion pieces stimulate discussion and response from the reader. Letters from readers are given greater prominence than in Western journals and add to the discussion. The articles themselves tend to be short as well as tentative, especially in Library and Information Services and Library Journal, with items fitting the description of "articles" or "essays" averaging only 5.3 pages in the Bulletin and less than 2.4 pages in Library Journal.

\section{Comparisons of Communication Content with Statements of Professional Objectives}

Finally, content studies may be useful for auditing communication content against formal statements of professional objectives or policy. One official policy statement can be taken to demonstrate this possibility. As the official organ of the China Society of Library Science, the Bulletin recently published "Library Work Regulations for Higher Education Systems in the People's Republic of China." Two sections concerning reference services read as follows:

\#8. University and college libraries should enhance readers' service work and, according to needs and conditions, set up various circulation counters and reading rooms, strengthen the

TABLE 2

RHETORICAL MODES/JOURNAL CATEGORIES

\begin{tabular}{|c|c|c|c|c|}
\hline & Bulletin CSLS & $\begin{array}{c}\text { Library \& } \\
\text { Info. Service }\end{array}$ & $\begin{array}{l}\text { Library } \\
\text { Journal }\end{array}$ & Total \\
\hline Articles & $43(4 b / 1 c)$ & $62(15 b / 1 c)$ & $107(13 b / 11 c)$ & 217 \\
\hline factual & & 27 & 65 & 120 \\
\hline description & 12 & 2 & 32 & 46 \\
\hline history & & $\overline{9}$ & 20 & 35 \\
\hline research & 2 & 4 & 2 & 8 \\
\hline work experience & 8 & 12 & 11 & 31 \\
\hline speculative & 15 & 35 & 47 & 97 \\
\hline Letters & $5(2 b)$ & $6(2 b)$ & $4(1 b)$ & 15 \\
\hline Commendation & 2 & 2 & - & 4 \\
\hline Exhortation & 10 & 4 & 6 & 20 \\
\hline Bib. essay & 4 & 1 & $11(2 b / 2 c)$ & 16 \\
\hline News & & 6 & 6 & 26 \\
\hline Reviews & $5(2 b / 2 c)$ & 3 & $4(1 b / 1 c)$ & 12 \\
\hline Reprints, etc. & $3(1 \mathrm{~b} / 1 \mathrm{c})$ & - & 6 & 9 \\
\hline Editorials & 1 & - & 1 & 2 \\
\hline
\end{tabular}

Note: $b$-includes bibliography; $c-$ includes citations 
service system, and increase the utilization of the collection.

\#9. University and college libraries should develop reference and information service work, compile various subject bibliographies and indexes, help the reader to find reference materials, and provide information retrieval and information analysis services. ${ }^{52}$

One can compare the official statements quoted above with the number and kind of items found in our analysis. One can also compare them with the published reports of Western observers. Despite a number of exhortations, slogans, and articles in the three journals studied here, one must conclude that mainland China still has much further to go in developing true access for the average user of libraries.

\section{CONCLUSION}

While mainland librarians appear to have made much progress in professional awareness, increased communication, and intensified determination to bring about reform since the Cultural Revolu- tion, much remains to be done. As one mainland librarian wrote (in a Western journal), "services and automation are backward. China is aware of her weakness ... and is trying to change." He was quick to admit that there are numerous difficulties to overcome before modernization of library and information service can be accomplished.

Nonetheless, the presence of extensive professional channels of communication, an increasing awareness of foreign professional standards and practice, and numerous programs of exchange are bringing hope for change. This study reveals a new self-consciousness among a growing body of library professionals. It demonstrates a strong concern for reform in various matters including personnel management. And it indicates an increased awareness of the need to provide and improve services. During the next decade, Chinese librarians should be able to consolidate the gains of recent years and demonstrate significant improvements in collection management and services.

\section{REFERENCES}

1. Sharon Rogers, "Academics Abroad: U.S. Librarians Visit the People's Republic of China," C\&RL News 46, no.8:399-403 (Sept. 1985).

2. Xingyun Luo, "Libraries and Information Services in China," Journal of Information Science 6, no.1:21-31 (Mar. 1983); Zheng Fan, "Consulting Service at the Library of Tianjin University," College \& Research Libraries 42, no.5:483-85 (Sept. 1981).

3. Thomas Y. Yeh, "A Profile of Academic Libraries in China," College \& Research Libraries 46, no.6:499-503 (Nov. 1985); Nelson Chou, "China Revisited," Association of Research Libraries, Center for Chinese Research Materials, Newsletter, no.36:2-4 (Spring 1984).

4. William Wong, "Opening up the People's Republic: Library Cooperation with China," Wilson Library Bulletin 55, no.5:336-41 (Jan. 1981).

5. Sharon Chien Lin, "Chinese Serial Publications on Librarianship: An Annotated List," Serials Review 11, no.1:7-20 (Spring 1985); Meng-Fen Su, "Current Library Science Journals in China," Serials Librarian 9, no.2:93-106 (Winter 1984).

6. Luo, "Libraries in China," p.27.

7. China Handbook (1985-86) (Hong Kong: Ta Kung Pao, 1985), p.293.

8. Luo, "Libraries in China," p.24.

9. Tony Evans, "China, the Inscrutable Phoenix: Libraries from Pre-Ming to Post-Mao," Aslib Proceedings 37, no.10:381-94 (Oct. 1985).

10. Wong, "Cooperation with China," p.339.

11. "Libraries," People's Republic of China Yearbook 1984 (Beijing: Xinhua, 1984), p.651.

12. Wong, "Cooperation with China," p.339; "Libraries," p.651-52.

13. Sharon Chien Lin, "Education for Librarianship in China after the Cultural Revolution," Journal of Education for Librarianship 24, no.1:24-25 (Summer 1983); Wong, "Cooperation with China," p.339; Lee-hsia Hsu Ting, "Library Services in the People's Republic of China: A Historical Overview," Library Quarterly 53, no.2:155-56 (1983); Evans, "Pre-Ming to Post-Mao," p.392; Harry Campbell, "The Present Revival of Scholarly Publishing in China," Scholarly Publishing 16, no.3:223-24 (Apr. 1985). 
14. Chi Wang, "An Overview of Libraries in the People's Republic of China," China Exchange News 12, no.3:2 (Sept. 1984).

15. You-mei Wang and A. R. Rogers, "Thirty Years of Library Development in the People's Republic of China," International Library Review 14:404-5 (Oct. 1982).

16. Wang, "Overview," p.2.

17. Lin, "Education," p.27.

18. Wang, "Overview," p.2; Lin, "Education," p.25.

19. Lin, "Education," p.27.

20. Lin, "Education," p.20.

21. Anis Khurshid, "Libraries in the Far East," in Encyclopedia of Library and Information Science, v.37, ed. Allen Kent (New York: Marcel Dekker, 1984), p.135.

22. Tsuen-hsuin Tsien, "China Library Association," in Encyclopedia of Library and Information Science, v.4, ed. Allen Kent and Harold Lancour (New York: Marcel Dekker, 1970), p.656-57.

23. Personal correspondence to the author, China Society of Library Science, Beijing, July 20, 1986.

24. Lin, "Education," p.24.

25. Huixiang Wang, "A Proposal Concerning Deciding on Awards through Discussion for Excellent Library Science Journals," (in Chinese) Bulletin of the China Society of Library Science, no.2:44 (1986).

26. In personal correspondence with the author (July 20,1986) the China Society of Library gave the Bulletin's circulation figures as follows: 30,000 total, of which the domestic number is approximately 28,000 , and those sent outside the P.R.C. approximately 2,000 .

27. Lin, "Serial Publications," p.17-19; Su, "Journals in China," p.103-4; C. Wang, "Overview," p.2.

28. Lin, "Serial Publications," p.17; Su, "Journals in China," p.103.

29. Lin, "Serial Publications," p.19.

30. Ibid.

31. "Thirty Years of the Shanghai Library," (in Chinese) Bulletin of the China Society of Library Science no.3:3-6 (1984); Ting, "Historical Overview," p.141-42.

32. Bernard Berelson, Content Analysis in Communication Research (New York: Free Pr., 1952), p.31-34, 43-52, 66-72, 98-105.

33. Lin, "Education," p.7.

34. Su, "Journals in China," p.97.

35. Yeh, "Profile," p.501-2.

36. Yeh, "Profile," p.502.

37. Ibid.; Ting, "Historical Overview," p.154.

38. Yeh, "Profile," p.502.

39. Chou, "China Revisited," p.3.

40. Fan, "Consulting Service," p.483, 485.

41. Rogers, "Academics Abroad," p.401.

42. Rogers, "Academics Abroad," p.401-2.

43. Kenneth L. Stubbs, "Academic Research Libraries: Recent Studies," Bowker Annual of Library \& Book Trade Information (New York: Bowker, 1985), p.417-23.

44. Evans, "Pre-Ming to Post-Mao," p.384.

45. Evans, "Pre-Ming to Post-Mao," p.388.

46. Carl E. Walters, "Facilities Offered for Research on Contemporary China by the National Library of Beijing," China Quarterly, no.85:146 (Mar. 1981).

47. "Focus on Library and Archival Research," China Exchange News 12, no.3:5-19 (Sept. 1984).

48. Chou, "China Revisited," p.3.

49. Rogers, "Academics Abroad," p.402.

50. Su, "Journals in China," p.96-98.

51. Qui Chang and Huang Xin, "Study of Library Science in China's New Period," (in Chinese) Bulletin of the China Society of Library Science, no.1:32, 36 (1982).

52. Bulletin of the China Society of Library Science, no.4:14 (1981) (in Chinese).

53. Luo, "Libraries in China," p.31. 